\title{
Role of morphological changes in newly born granule cells of hippocampus after status epilepticus induced by pilocarpine in hyperexcitability
}

Julian Tejada ${ }^{1,2}$, Norberto Garcia-Cairasco ${ }^{2}$, Antonio C Roque ${ }^{1 *}$

From Twenty First Annual Computational Neuroscience Meeting: CNS*2012

Decatur, GA, USA. 21-26 July 2012

Newly born dentate gyrus (DG) granule cells (GCs) after Status Epilecticus induced by pilocarpine (PILO) exhibit morphological changes including narrower arborizations, greater number of branches and more endings in the inner molecular layer (IML) [1]. The increased concentration of dendrites in the IML where granule cell axons (mossy fibers) sprout in epileptic animals and make extensive recurrent excitatory synapses may contribute to

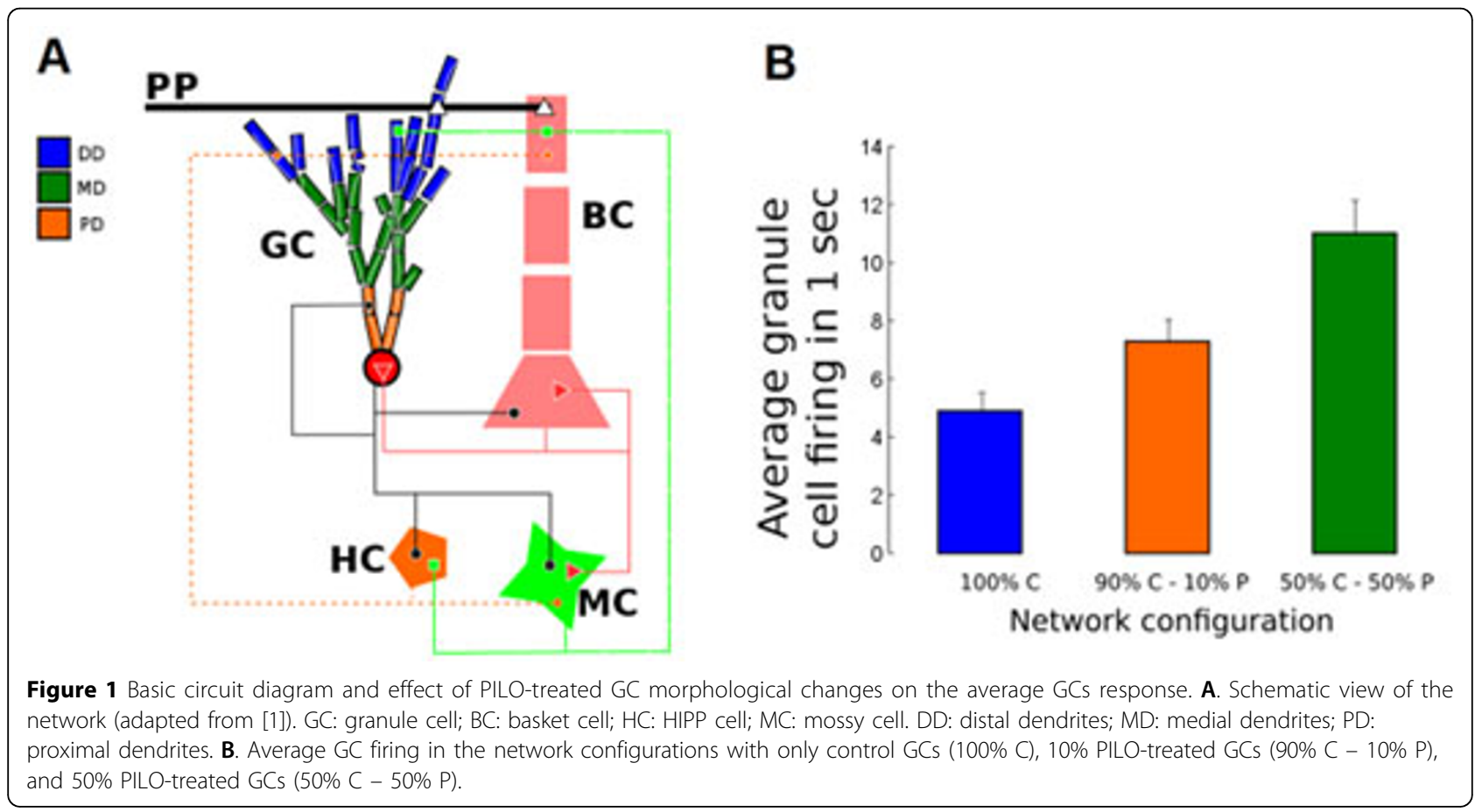

\footnotetext{
* Correspondence: antonior@ffclrp.usp.br

'Departamento de Física, FFCLRP, Universidade de São Paulo, Ribeirão Preto,

SP, 14040-901, Brazil

Full list of author information is available at the end of the article
} 
enhance the DG hyperexcitability. A previous DG network model has shown that mossy fiber sprouting has a crucial role on hyperexcitability with only $10 \%$ sprouting being enough to generate spread of activity to all GCs in the network [2]. However, the additional effect of GC morphological changes on DG hyperexcitability is as yet unknown. Here we used the DG model [2] to evaluate the effect of different GC morphologies on the network activity. We replaced all reduced GC models of [2] with morphologically detailed models coming from tridimensional reconstructions of newly born doublecortin-positive DG GCs [1]. The scheme of the network connections is shown in Figure 1A. Our sample of morphologically reconstructed GCs includes 20 from PILO-treated rats and 20 from control rats. Our cell models were constructed in NEURON and their ionic channels and maximum conductance distributions were the same as [2] taking into consideration the shorter arborizations of the PILO-treated cells. Our "control" network model is exactly the same as the topographic ring network of [2] with $10 \%$ sprouting available in ModelDB with the 500 original GC models replaced by morphologically reconstructed cells randomly chosen from our control sample. From our control network model we constructed two other models: one with $10 \%$ of the GCs (chosen randomly) replaced by cells chosen randomly from our PILO-treated sample and the other with the fraction of PILO-treated GC cells increased to $50 \%$. The networks were submitted to focal perforant-path stimulations as in [2] and to obtain averages we ran 100 simulations for each network (connections between cells were created anew before each run). Our control network model produced a response similar to the one of the original model [2], showing that the insertion of GCs with realistic morphologies did not affect the $10 \%$ sprouting DG hyperexcitability (Figure 1 B, 100\% C). In contrast, when a few amount of PILO-treated GCs were inserted the excitability of the network increased (Figure 1B , 90\% C - 10\% $\mathrm{P})$ and the increase was higher when the amount of PILOtreated GCs was larger (Figure 1 B, 50\% C - 50\% P). However, the effect of the insertion of PILO-treated GCs was only visible in combination with mossy fiber sprouting. Our results suggest that changes in GC morphology alone are not enough to affect the DG hyperexcitability but when these changes occur in the presence of other alterations such as mossy fiber sprouting they could enhance the DG hyperexcitability.

\section{Acknowledgements}

JT is the recipient of a Post-Doctoral Fellowship from CNPq, Brazil. NGC and ACR are recipients of grants from CNPq, FAPESP, FAPESP-Cinapce, CAPESPROEX, CNPq-Research Fellowships, Brazil.

\section{Author details}

'Departamento de Física, FFCLRP, Universidade de São Paulo, Ribeirão Preto, SP, 14040-901, Brazil. ${ }^{2}$ Departamento de Fisiologia, FMRP, Universidade de

São Paulo, Ribeirão Preto, SP, 14049-900, Brazil.

Published: 16 July 2012

\section{References}

1. Arisi GM, Garcia-Cairasco N: Doublecortin-positive newly born granule cells of hippocampus have abnormal apical dendritic morphology in the pilocarpine model of temporal lobe epilepsy. Brain Res 2007, 1165:126-134.

2. Santhakumar V, Aradi I, Soltesz I: Role of mossy fiber sprouting and mossy cell loss in hyperexcitability: a network model of the dentate gyrus incorporating cell types and axonal topography. J Neurophysiol 2005, 93:437-453.

\section{doi:10.1186/1471-2202-13-S1-P56}

Cite this article as: Tejada et al:: Role of morphological changes in newly born granule cells of hippocampus after status epilepticus induced by pilocarpine in hyperexcitability. BMC Neuroscience 201213 (Suppl 1):P56.

\section{Submit your next manuscript to BioMed Central} and take full advantage of:

- Convenient online submission

- Thorough peer review

- No space constraints or color figure charges

- Immediate publication on acceptance

- Inclusion in PubMed, CAS, Scopus and Google Scholar

- Research which is freely available for redistribution

Submit your manuscript at www.biomedcentral.com/submit 